\title{
Abraham Zabludovsky as a representative of brutalism in Mexican architecture
}

\author{
Elżbieta Żuławska-Sobczyk
}

\begin{abstract}
Brutalism was a trend that appeared in architecture in response to the International Style, with preference for the aesthetics of machines and clean geometric forms striving for lightness and stylistic purity. Le Corbusier is considered to be the precursor of this style, but its concept was best presented both in theory and practice by Alison and Peter Smithson. The idea of expressing form, the sincerity of material, and deriving from what could be found in the area of construction has spread throughout the world. In Mexico, an architect of Polish descent, Abraham Zabludovsky, became an advocate of Brutalism and, along with Teodor Goznalez de Leon, has created many buildings which are now iconic for the of Mexico city. This study aims to present the case of Zabludovsky's architectural concepts.
\end{abstract}

Keywords: Zabludovsky, Brutalism, New Brutalism

\begin{abstract}
o
ABRAHAM ZABLUDOVSKY, COMO REPRESENTANTE DEL BRUTALISMO EN LA ARQUITECTURA MEXICANA

El brutalismo fue una tendencia que apareció en la arquitectura en respuesta al estilo internacional, con preferencia por la estética de las máquinas y las formas geométricas limpias que luchan por la ligereza y la pureza estilística. Se considera que Le Corbusier es el precursor de este estilo, pero su concepto se presentó mejor en teoría y práctica por Alison y Peter Smithson. La idea de expresar la forma, la sinceridad del material y derivar de lo que se puede encontrar en el área de la construcción se ha extendido por todo el mundo. En México, un arquitecto de origen polaco, Abraham Zabludovsky, se convirtió en un promotor del brutalismo y, junto con Teodor Goznalez de León, ha creado muchos edificios que ahora son icónica de la ciudad de México. Este estudio pretende presentar el caso de los conceptos arquitectónicos de Zabludovsky.
\end{abstract}

Palabras clave : Zabludovsky, Brutalismo, Nuevo Brutalismo

Elżbieta Żuławska-Sobczyk, - Latergrupa, PTSL, Email: elzbietazulawska@wp.pl https://orcid.org/0000-0002-9282-9769 


\section{Introduction}

In the 19th century, Mexican architecture was dominated by architectural trends imported from Europe and the United States. All forms of the so-called "neo" styles were positively received by investors. At the same time, the elements of Colonial style were still commonly found in projects. The first half of the twentieth century brought fascination with the International Style and Functionalism, which remained present in Mexican architecture until after the Second World War. Over the years, less widespread design trends made their appearance in Mexico as well (Bergdoll, Comes, Liernur, del Real 2015), along with references to regional forms and vernacular architecture, such as the work of Luis Barragan. Another reference to international ideas was the introduction of Brutalism onto Mexican soil with its specific Mexican themes, carried out mainly by Abraham Zabludovsky and Teodoro Gonzalez de Leon.

\section{Brutalism as a trend in architecture}

The 20th century was an extremely turbulent time in the history of architecture, and resulted in many original artistic concepts. It was also the period in which an unusual multitude of styles coexisted. The beginning of the century was marked by domination of the International Style which used the aesthetics of a machine. With time, new trends appeared, with more expressive stylistic "language". Finally Postmodernism arrived, which constituted a certain denial of what was praised at the beginning of the century. Among those struggles, Brutalism was born.

One of the precursor of Brutalism was Le Corbusier. After years of admiration of buildings characterized by the machine style, he changed his attitude towards architecture, shifting his focus to more expressive forms that not only did not hide, but even proudly displayed the materials from which they were constructed. It was the observation of the lives of "simple" people and their homes that made Le Corbusier change his approach. He came to the conclusion that abstract, functionalistic forms cannot be understood by uneducated people. Also, they do not evoke emotions, as is the case with buildings erected in the spirit of traditional architecture.

"However, he noticed how much people identify with houses with less sophisticated forms made of local materials. He understood that in vernacular architecture, in primitive buildings of rural builders, there is a lot of emotional potential, and he decided to use it in his work. "Wojciech Niebrzydowski (Niebrzydowski 2018)

The so-called Unité d'Habitation in Marseille (Niebrzydowski 2018) (B) is considered as one of most important building erected in accordance with these principles (Banham 1966). This structure was a response to new challenges that 
architecture had faced after the Second World War. Le Corbusier believed that after the catastrophe of a global conflict it became necessary to abandon abstract machine forms and take care to provide decent housing conditions in the post-war world. It was in this building that for the first time he used concrete in its unprocessed form - after removing the formwork, the walls, pillars and ceilings were not smoothed, they remained rough, and bore marks of the formwork boards. This type of workmanship has been called béton brut and has become the most recognizable feature of Brutalism in architecture. Other features of this structure, which have made their way into the works of architects creating in the Brutalist trend are:

- chiaroscuro design of the façade;

- massive and squat form of a building;

- emphasizing contrasts between forms;

- firm articulation of blocks;

- functions of particular fragments of a building reflected in the façade;

- cheap and "honest"1 use of materials.

Le Corbusier was not the first architect to include more or less evident threads of Brutalism in his works, but he exerted the strongest influence on the post-war architects who designed in this style. A British couple, of Alison and Peter Smithson worked towards the popularization of the principles of Brutalism among architects. On September 11, 1953 in London an inauguration of the Smithsons' exhibition titled "Parallel of Life and Art" took place, which contributed to the recognition of this trend. The exhibition presented photographs of several objects used in everyday life, as well as artistic exhibits in varying scales and approximations. The photographs were hung on rigid boards of different sizes, which were suspended in space in such a way as to create a spatial composition forcing viewers to move between objects, approaching them and moving away, and changing positions to see particular details. At the same time, the whole setup was so arranged that the exhibition could not be seen in its entirety from one place. These endeavors were aimed at "drawing" visitors inside the created structure and showing relations between seemingly unconnected objects.

"The issues of movement, discovering spatial relations, and unconventional ordering principles will be the key problems of New Brutalism." (Niebrzydowski 2018).

In the theory created by the Smithsons, called "the New Brutalism", four ideas were fundamental: the idea of sincerity of material, the "As Found" idea, the Image idea, and the idea of linking life and architecture $^{2}$. The New Brutalism theory was taking shape somewhat parallel to practice, therefore not all of its principles can be found in structures assigned to this style, but these four ideas had the greatest impact on architects designing in it (Niebrzydowski).

The New Brutalism should be considered the theoretical basis of Brutalist architecture, nevertheless at the same time it must be remembered that this theory 
was taking shape simultaneously with its physical representations, even long after the first buildings bearing the characteristics of this trend have been erected. It is also noteworthy that despite the fact that buildings were created in this spirit around the world, the multitude of interpretations of the same principles was so large that many variations of Brutalism arose. It is all the more natural due to the fact that New Brutalism enforces an interplay with regional conditions. Le Corbusier's buildings erected in France, such as the La Tourette monastery, have different appearance than those built in the Indian Chandigar, and the difference is even bigger with those created in Poland, such as the now-defunct railway station in Katowice by the so-called “Tigers” (Wacław Kłyszewski, Jerzy Mokrzyński, Eugeniusz Wierzbicki).

\section{Abraham Zabludovsky's path to architecture (1924-2003)}

Abraham Zabludovsky was born on June 14, 1924 in Bialystok. His family left Poland three years after his birth in search of better life and new opportunities. Good friends of the family had settled in Mexico a few years before, and since this country welcomed immigrants at the time, it became the place of choice for the Zabludovskys. Abraham's younger brother, Jacobo, was born there, to become a renowned Mexican journalist later in life. The parents instilled in children that "the only wealth is the intellectual wealth, the one that arises from thinking, meanwhile the rest comes and goes" (de Garay 1995). Abraham grew up in a rather poor district of La Merced, in which not only the native Mexicans but also large groups of immigrants lived. It was there that he watched the life of the city and its problems, and thanks to the Sunday walks with his family he got to know new places. Those experiences contributed to the development of his passion for architecture. It took a long time, and many home moves for the family to improve its financial condition enough to finally settle down in a more prestigious neighborhood of La Condesa.

In 1949, Abraham Zabludovsky graduated from the Escuela Nacional de Arquitectura. His Master's thesis, for which he received an honorary distinction, was based on the idea promoted by Le Corbusier in the Villa Radieuse project. The latter project focused on separating pedestrian and car traffic, and placing large housing units in green spaces. Guided by this logic, Zabludovsky proposed a reorganization of the area located in the ring of Avenida Mexico and Amsterdam Street, and construction of 20-storey residential buildings located in the green surroundings of the Mexico Park. As a consequence of such urban planning of this area, the Avenida Mexico and many historic buildings were to disappear. During his later professional career Zabludovsky came to the conclusion that such thinking was wrong and would bring more harm than good for the urban space.

In the first years of his professional activity, Zabludovsky primarily designed single-family houses. He received his first serious engagement thanks to his uncompromising criticism of the then-dominating Colonial and Californian styles 
of the houses of the rich Mexicans. This criticism gained him respect in the eyes of the future investor, and resulted in constructing a single-family house of his design, now long demolished, in the district of Las Lomas de Chapultepec. It was the first of his numerous designs of single-family houses.

Zabludovsky's work on single-family houses led him to the conclusion that "(...) in the design of a house I experienced a number of difficulties, as it is only logical, because a house represents a problem of a personal, emotional nature for the client" (De Garay 1995) It also taught him patience and meticulous care of the funds that were allocated to the investment. Another habit of Zabludovsky that laid the foundation for his future professional career were his frequent visits to the construction site. It was there that he learned many technical solutions and ways of optimizing the costs of building and organizing construction works.

During his professional activity he came to the conclusion that architectural design is based on three pillars:

- a program, that is, a set of precise guidelines as to what function should the structure and its particular spaces fulfill;

- a plot of land in a specific location, and therefore everything that a given area and its neighborhood brings with it as a consequence;

- a „memory of the place”, or a broadly understood history of the place along with the emotional charge associated with it.

These three factors, according to Zabludovsky, were the determinants of the project, but the interdependencies between them could be different and can change within individual cases. At the same time, they could cause limitations as well as inspirations for a given project. Of course, there were other factors that affected the design, but the three mentioned above, in Zabludovsky's opinion, always occured, and were vitally important.

In the 1950s, Zabludovsky began working with Teodoro Gonzales de Leon. The two architects knew each other and were friends since their studies, but it was only in later years that they decided to combine their strengths in the professional field. Their cooperation resulted in many emblematic constructions in Mexico. Despite carrying out many contracts together, the team's cooperation was loose. They did not set up a joint studio, rather pooling forces for a specific project while simultaneously carrying out other jobs separately. Their studios were located in the immediate vicinity to each other, and the architects visited one another frequently, meanwhile the offices remained independent (Hayer 1978). Their projects were usually associated with large investments concerning public structures and multi-family buildings. They created a perfectly complementary team, with Gonzalez de Leon designing in a more orderly and systematic way, consistently verifying his ideas with Modulor ${ }^{3}$, while Zabludovski was more impulsive, and his mind was constantly open to new ideas and stimuli. He used to say "for me it's enough that something is correct" (Hayer 1978). Zabludovsky and Gonzalez de Leon were in- 
spired by the same architects and similar ideas, but each of them drew different conclusions from these teachings. The evolution of their work was also similar: together they came to new ideas and tried to implement them in new projects. They did not turn themselves away from the new thoughts coming from the outside, often boldly drawing on them. They were never afraid of changing previously selected avenues of design. All this resulted in many years of fruitful cooperation, testimonies of which can be often encountered in Mexico, including its capital.

\section{The works of Abraham Zabludovsky}

It is hard to say how much did Zabludovsky know about the Smithsons' postulates, but he certainly knew the work of Le Corbusier. His approach to design changed in the same way as the one of his French master. However, despite adhering to similar ideals, the paths they chose were slightly different.

Zabludovsky in his work approached the design in a practical but expressive way. On the one hand, he aimed to create his buildings as the works of art, but on the other hand they remained functional and practical to use. He tried to adapt to local conditions and draw as much as possible from the pre-existing situation on many levels. A very important aspect of his work was not only to care for the investment at the construction stage, but also at the stage of its subsequent use. He paid extreme attention to keeping the investment within the limits of the budget, and to reduce the future maintenance costs to the minimum.

Such an approach to architecture resulted in Zabludovsky turning to create structures bearing the distinctive features of Brutalism. In his opinion, structural design constituted a decoration of the actual building, therefore there was no need to cover it, as it was customary in constructions erected in the International Style. Many of his designs were based on concrete, because he considered it to be the most effective, the cheapest, and also the most plastic material. At the same time, in Zabludovsky's opinion, concrete did not require further processing at the final stage of erecting a building. In order to give different appearances to his buildings, and to connect them better to the spatial context, he was adding different aggregates to the concrete to obtain different colors, reflections, weights and by working with local workers he get a special surface of concrete (Maluga 2017). He also often used the so-called brise soleil (Maluga 2015), which allowed not only to make the façade more attractive, but also improved the parameters of solar exposure of indoor rooms, which is a considerable problem in Mexican conditions.

Many architects advertise their design postulates while building their own home. Zabludovsky did not differ in this respect from his colleagues. Therefore, when designing his house in 1969, he created an artistic manifesto. On an irregularly shaped plot, on a steep slope, he built a house opening into a gorge (Heyer P. 1978). The building had a dynamic form, with several fragments organically following the 
slope line. The architect had to cope with difficult conditions of that irregular terrain, thanks to which the building obtained an originally located entrance. One can approach the house over a concrete platform that connects it with the access road. On this level there is also an entrance to the building in form of a pavilion, and the remaining part, that also serves as a roof of the proper part of the house, consists of a terrace and a view point. The main section of the house, together with representative rooms, is located on the floor below and opens with a glass wall onto the side of the ravine. The entire structure has been designed so as to ensure the most attractive views from any place by means of horizontal distribution of rooms. With such large glass paneling and view openings, an important issue was also to solve the problem of sun screening, without which any indoor space can get inexorably hot in the Mexican climate. Zabludovsky coped with this issue with pushing windows into the wall and away from the façade, creating niches or eaves of a kind, that protected the rooms from heating up. The building was erected mainly from concrete, which gave it a heavy and massive appearance. However, addition of marble as an aggregate resulted in its original color and texture (Maluga 2017).

Basing on Zabludovsky's own house, there are several typical features that can be traced in most of the residences he designed. Buildings are usually oriented along the north-south axis, which allows to expand the eastern and western façades. The architect also tried to arrange houses in such a way that would enable their users to experience the best views available on a plot. The ground plan of a house is designed on either one or two floors, depending on the requirements of the land. Specifics of a location and the logic of construction are tackled through the primacy of functionality and budgetary rationality during construction over the formal design principles. The day area has been functionally separated from the sleeping quarters; the latter are usually smaller, but they enjoy the immediate vicinity of terraces. This is usually possible thanks to placing bedrooms on upper floors. At the same time, the day area is dominant in the whole arrangement, but the rooms that constitute it "disappear" in space. Despite the strong emphasis on functionality and rationality of space on terraces and in the surrounding gardens, organic forms appear as an addition. They are inherently less universal, but their role and scale is variable (Adria 2000).

After years of designing single-family houses, the time came for Zabludovsky to create housing facilities of a much larger scale. In his professional career he had a chance to design buildings for both the poor social strata, and for the socalled middle class. The investors were large state organizations as well as private individuals.

In his projects he was guided by several basic principles that, in his opinion, helped to create a better space in terms of utility, aesthetics, and economy. These principles included, among others, a conviction that the accessways should be maximally limited, as they raise the cost of construction per square meter of a flat, while 
their function does not affect the improvement of housing conditions. Thanks to this reasoning, long corridors are absent in his projects. The organization of multi-family buildings has always consisted of placing two, three or four apartments on a floor, so that they are accessible from a centrally placed communication shaft (staircase, often equipped with an elevator), and getting to them does not require walking along additional corridors. At the same time, such a distribution of flats allowed residents to feel the exclusiveness and helped to create social bonds that are difficult to establish with a large number of neighbors.

Both in the case of single-family houses and larger scale buildings, Zabludovsky used materials that did not require application of additional finishing layers, such as plaster or paneling with other materials. Such a solution was possible due to the frequent use of concrete and brick, because their surfaces did not require additional processing. This allowed not only to reduce the budget at the construction stage, but also lowered the cost of maintenance during years of use.

Zabludovsky in his projects tried to strictly adhere to the budget imposed on him. This was as much the case with the low-standard projects, as with the luxury ones. As a man with experience not only in architecture, but also in construction and business, he had necessary qualifications to realistically approach the execution and design work, and not force additional expenses on an investor.

It should be emphasized that, despite the fact that Zabludovsky was heavily influenced by the masters of European architecture like Le Corbusier, Mies van de Rohe, or Richard Neutra, he did not forget about the specific needs of his compatriots. In his projects he remembered to provide the inhabitants with a utility space, which for every Mexican home is an indispensable element of their household, and it only differs depending on the material status and spatial possibilities of the owners.

One of the first large-scale residential estates that Zabludovsky built in 1969 in cooperation with Teodoro Gonzalez de Leon was the La Patera community (Gonzalez de Leon, Zabludovsky 1976; Canales 2017). The investment was carried out on behalf of FOVISSTE (Fondo de la Vivienda para los Trabajadores al Servicio del Estado, an institution organizing construction of apartments for state employees) and aimed at providing affordable housing standards. The estate had 1760 flats in building complexes of between 100 and 120 apartments each. Such grouping of buildings was forced by regulations tackling to the distribution of residential buildings. Utilizing a variable number of floors, from two to five, the architects achieved a diversified structure of buildings, which allowed them to adapt to the conditions of solar exposition, regardless of the terrain, and to properly ventilate the estate in order to provide residents with better living conditions. Diverse height of the buildings also allowed to add variability to the community, which Zabludovsky personally considered as important issue, because he fought against "boredom" in architecture and even accepted the chaos in space as long as it would prevent the monotony (de Garay 1995). The buildings were designed in a modular way, in order to adapt 


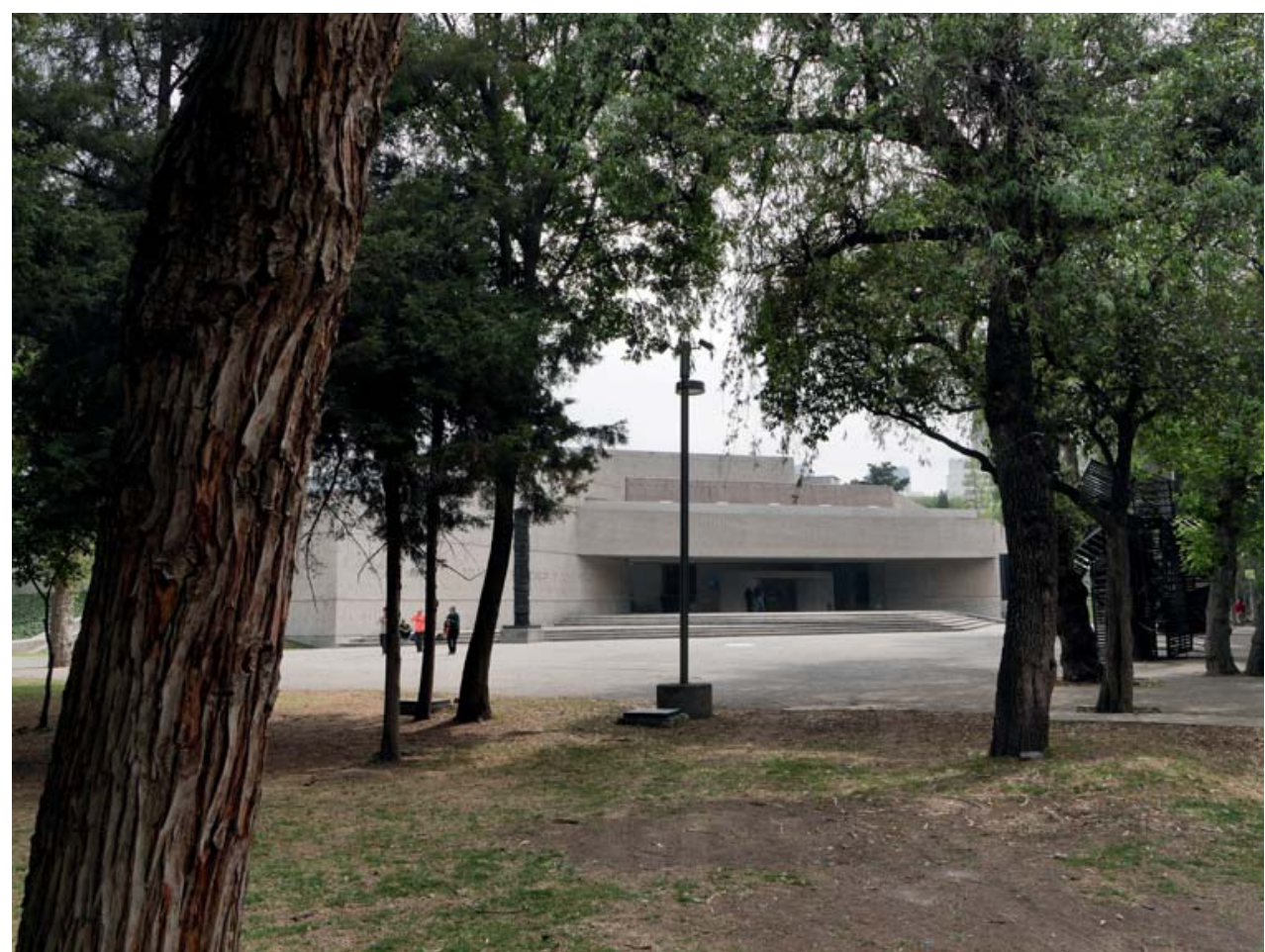

[Fig 1] The Rufino Tamayo Museum. General view

to the requirements of brick structures. Sanitary installations were placed in every apartment in a way that allowed freedom of interior design. This was a clear influence of Le Corbusier's thoughts and one of his five principles, that of a "free plan"4.

After completing this investment, Zabludovsky ceased to design social housing for many years. It was only in 1992 that he returned to this issue on the occasion of the La Cantera project.

Not only the design of housing estates required Zabludovsky to unite design forces with Teodoro Gonzalez de Leon. The two architects had many successful projects also in the field of public buildings. The most famous of them, especially among tourists, is the Rufino Tamayo Museum located in the Chapultepec Park, in the vicinity of the frequently visited Anthropological Museum. The painter Rufino Tamayo himself chose Zabludovsky as the designer of a building that would house a collection of about 200 pieces representing various styles of contemporary painting, donated by him to the state $(\mathrm{M})$. Due to the prestigious nature of the location, the investment could not take off for many years. Places like Chaplultepec are considered by the Mexican people as "exceptional", which is why many thought it would be unfair to offer it to this particular artist. This issue led to mounting problems and avalanche of criticism, with which Tamayo and Zabludovsky fought for ten years. In 


\section{Elżbieta Żuławska-Sobczyk}

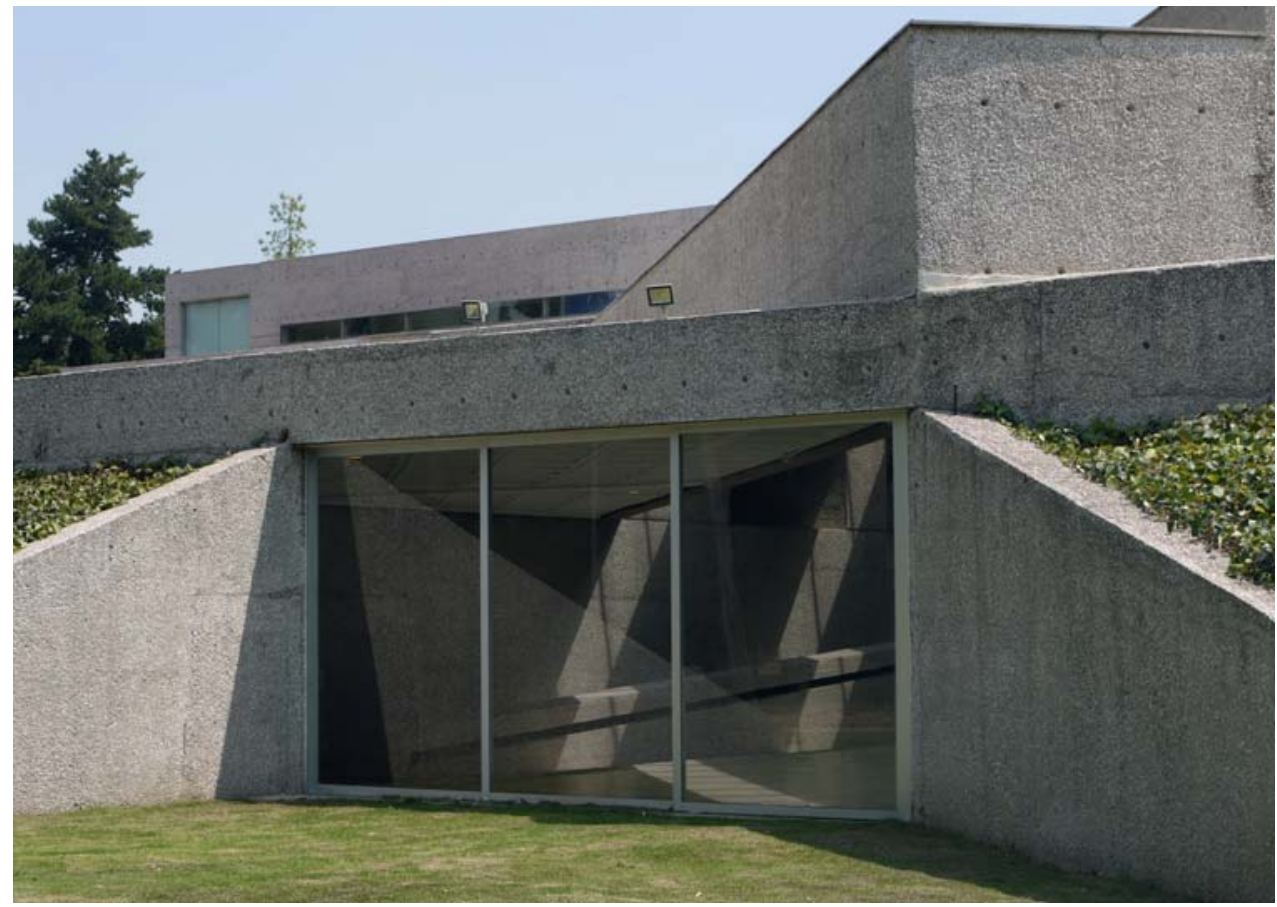

[Fig 2] The Rufino Tamayo Museum. Window

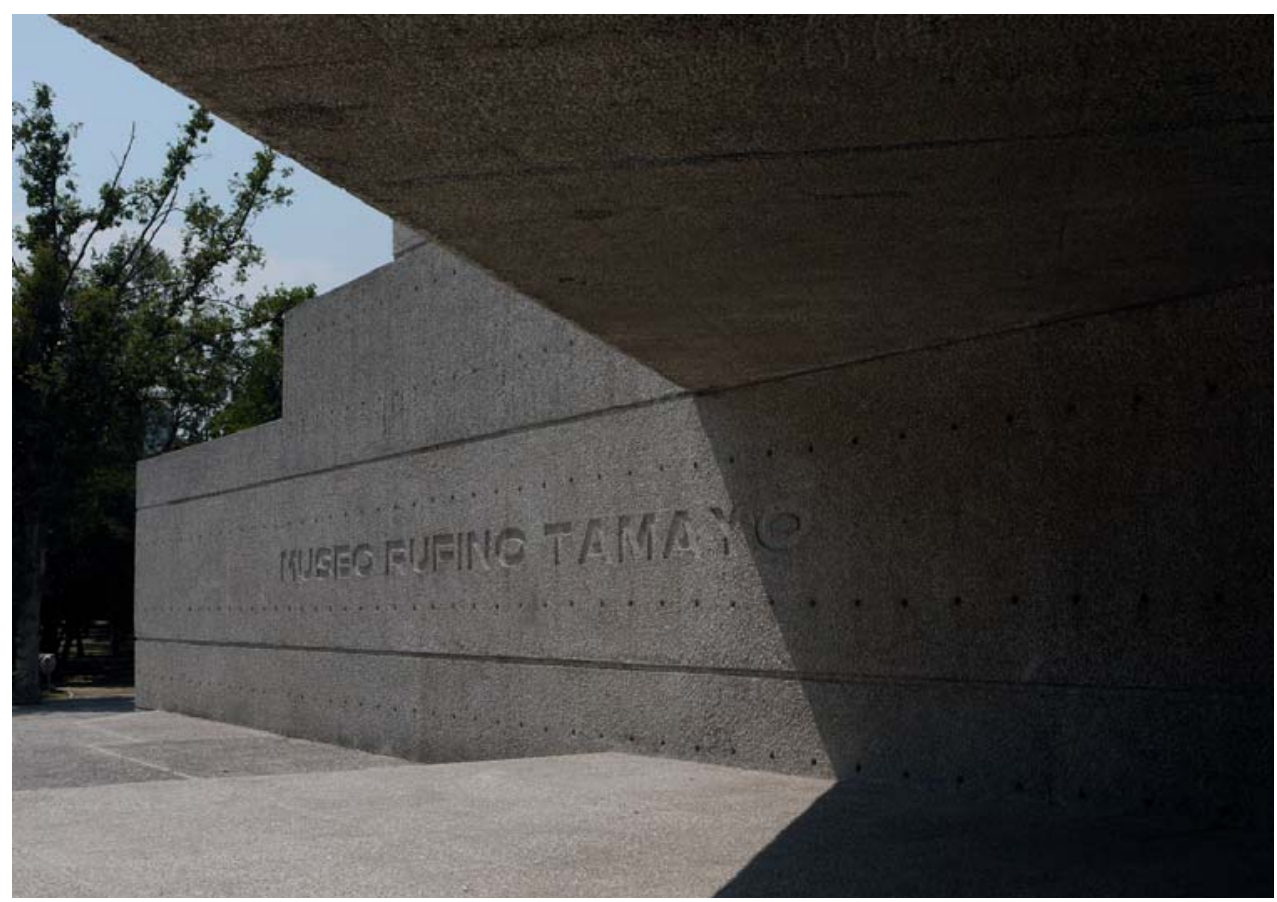

[Fig 3] The Rufino Tamayo Museum. Detail of the entranc. 
1979, favorable political conditions finally came about and with the financing from two corporate sponsors, the Grupo Industrial Alfa de Monterrey, and Televisa, they managed to commence the construction of the museum, which lasted another two years. In 1981, the museum was inaugurated.

In Zabludovsky's opinion, the location, in combination with the function that the object was supposed to serve, called for a need to create an expressive form, but not excessively aggressive towards its surroundings. As a result, a terraced, multidimensional block has been partially sunken into the ground. Its shape was inspired by a pyramidal form from a pre-Columbian archaeological site of Zacuelo (AD). The erection of such an expressive form was possible, once again, thanks to the use of concrete with the addition of aggregate, which allowed to achieve a more porous wall structure and to dye it into a new color. It houses a typical, full-size museum, with exhibition halls, but also a library, an auditorium, a cinema room, a café, and several office rooms. The entrance to the building leads through a foyer, which becomes an interior patio that brings together the space of the museum. This effect was achieved by significantly raising the ceiling above the entrance zone, and lowering the floor in the center. Exhibition rooms are divided thematically and correspond to various "schools" of contemporary art. They are accessible from the passageway which has been designed in such a way as to allow visitors to move freely around the rooms and make independent decisions on which space they want to enter and which they want to avoid. In this way Zabludovsky had solved the problem which he noticed while visiting museums around the world. He observed that many of them merely adapted spaces that had not been originally created for exhibiting pieces of art, and often visitors felt lost and had difficulties finding what was of particular interest to them (de Garay 1995). Another problem that he noticed while visiting various exhibitions was lighting. Based on these observations, he came to a conclusion that the pictures should be illuminated with artificial light, while the natural light served better to illuminate sculptures. For this reason, the museum has been designed to receive a lot of natural light, which allowed visitors to admire the sculptures against the background of Chapultepec. At the same time, windows were placed in such a way as to prevent the sunlight from "intruding" the interior.

Another widely known project realized by the tandem of Zabludovsky and Gonzalez de Leon is the prestigious Colegio de Mexico. The team won a contest and the college building was erected within 12 months. In this project, as in the case of the Rufino Tamayo Museum, the architects resorted to a motif of an internal patio, but this time its form was adapted to the undulating terrain of the plot, which was peculiarly incorporated into the building. The school is located in a zone that geologically consists of solidified volcanic lava. Effectively, it is an area with a very irregular structure, with numerous depressions and voids in the terrain, and peppered with scarce vegetation. The two architects decided to organize their structure in a way that the unmodified portion of this almost lunar landscape would become 


\section{Elżbieta Żuławska-Sobczyk}

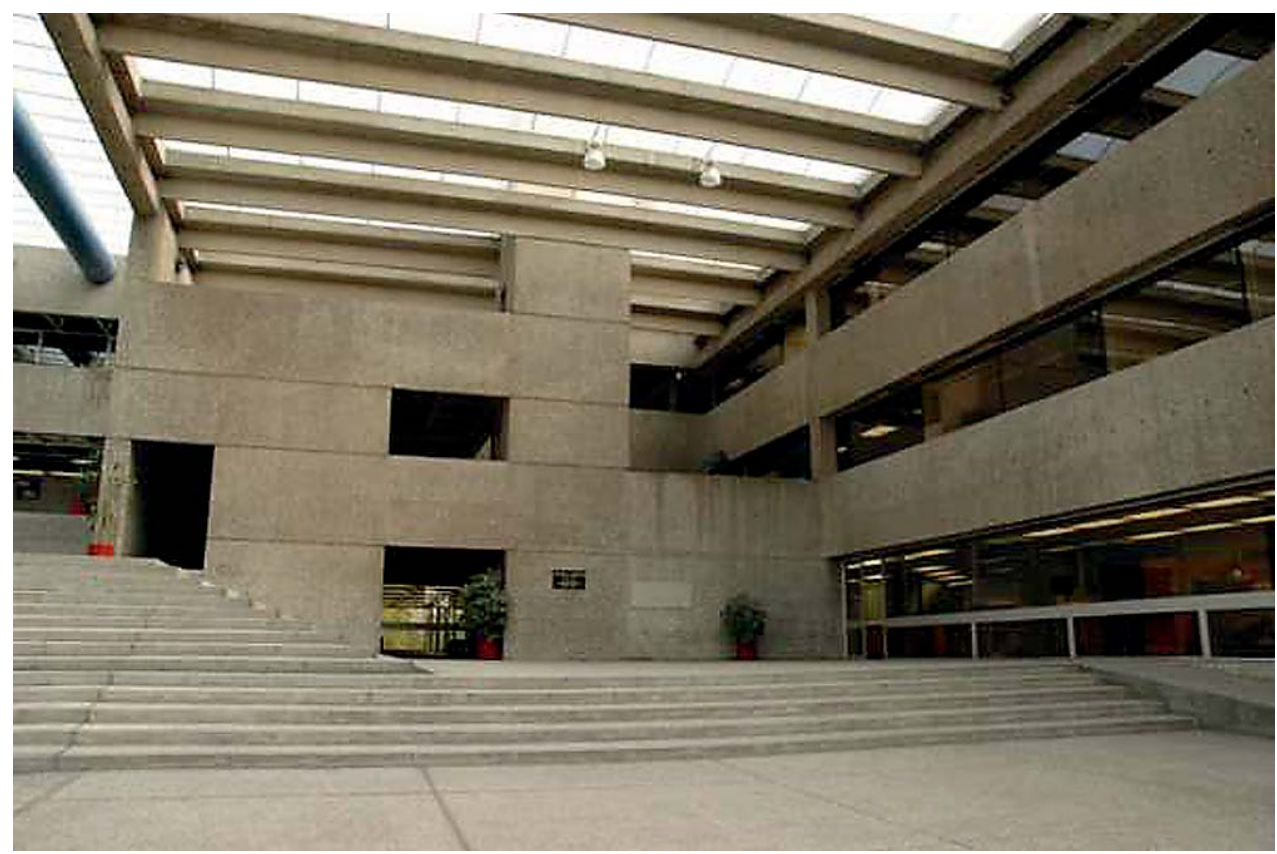

[Fig 4] Colegio de Mexico, interior,

(foto: Afrappe, license CC BY 3.0, https://commons.wikimedia.org/wiki/File:Colmex007.JPG)

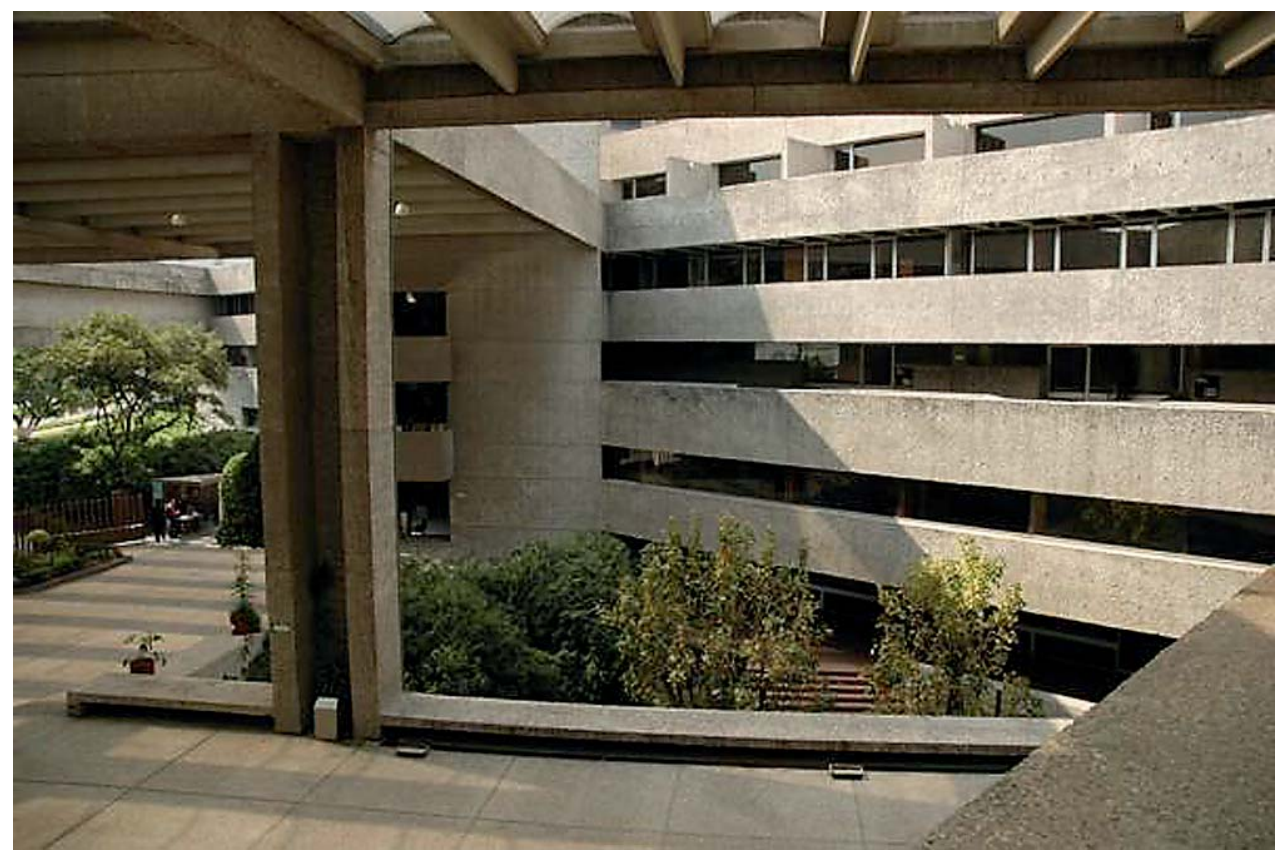

[Fig 5] Colegio de Mexico, patio,

(foto: Afrappe, license CC BY 3.0, https://commons.wikimedia.org/wiki/File:Explanada_de_El_Colegio_de_M\%C3\%A9xico.jpg\#filelinks) 


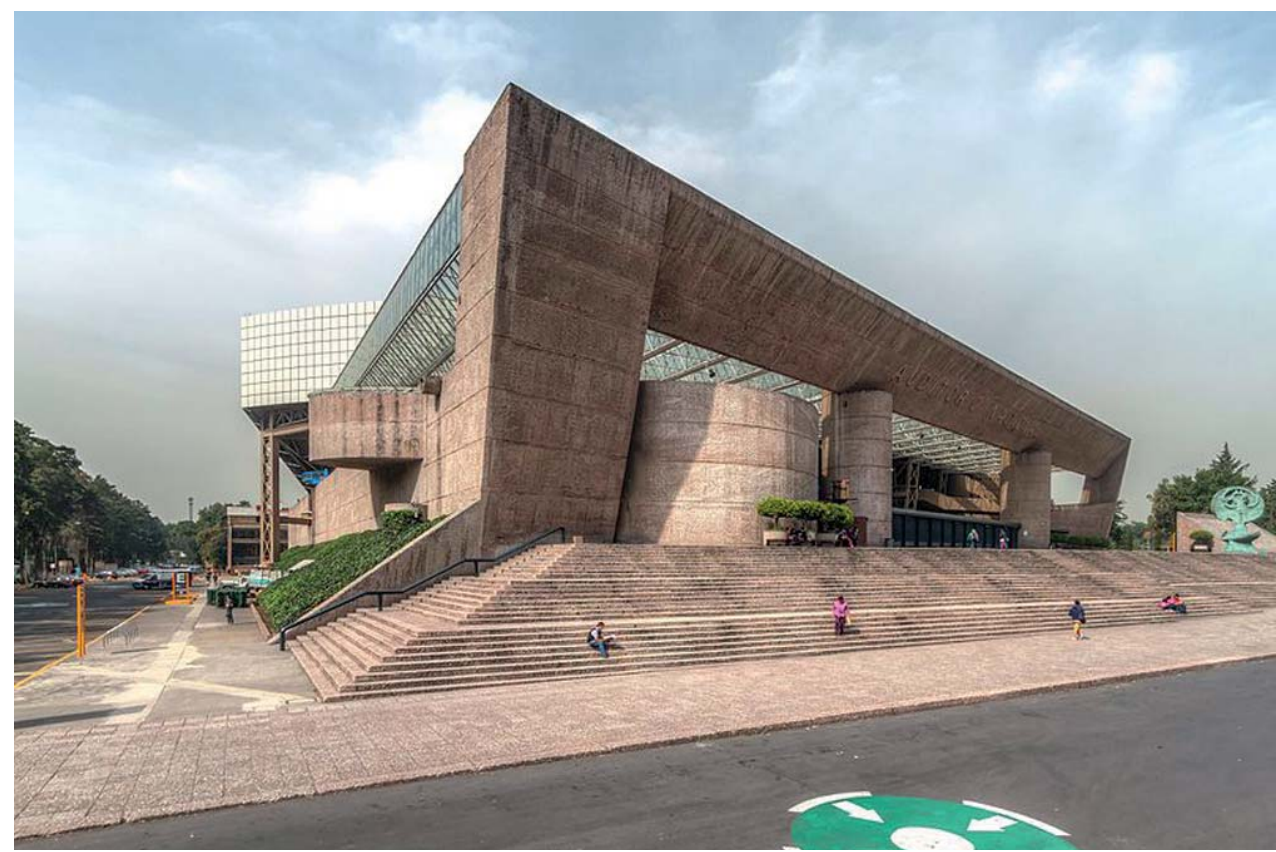

[Fig 6] Auditorio Nacional

(foto: Pierre-Selim Huard, license CC BY 4.0, https://en.m.wikipedia.org/wiki/File:Ciudad_de_ Mexico_-_1194_-_Auditorio_Nacional.jpg)

its center. As a result, the volcanic rock constituted the patio "floor", around which "grew" the building's form. It is worth mentioning that the patio is located in a natural basin, so the entrance to the structure was located halfway up the depression, and the particular functional sections of the building have been placed at different levels above and below it. One of the walls of the courtyard has remained virtually undeveloped, thanks to which the patio offers views towards the Ajusco volcano that is framed, in a way, by vertical walls and a monumental, 40-meter-long reinforced concrete beam that spans them.

In terms of the environmental conditions, the entire compound has been designed to match the landscape as much as possible. As a result, many lines have an organic nature rather than conforming to an organized, perpendicular grid. At the same time, the architects had to cope with 13 meters of difference in elevation of the plot, which they fully incorporated into the structure.

The shape of the building is divided into three full stories, but the levels +1 and -1 are further divided into mezzanines. Next to the entrance there is a library that nowadays boasts of an outstanding collection of books. The classrooms are located above it, and at the highest level there are rooms for professors and administration offices. At level -1, features such as an auditorium, a café, and student rooms have been placed. All these levels and mezzanines are connected by wide stairs of 
a theatrical character. Horizontal communication was resolved in the form of open corridors that allow free circulation of air flowing through the patio.

Both in terms of construction and wall filling, the structure is made of unfinished concrete. Again, marble was added as an aggregate to obtain a unique color of the walls. At the same time, each façade has been designed in a way that either limits or increases the sun exposure as effectively as possible for every room.

As a very prolific architect, Zabludovsky has left a strong mark on the landscape of Mexico city. He created about two hundred buildings of various sizes, many of which may be admired to this day. Among constructions not described above are: the Delegacion Cuauhtemoc (Office of the Cuauhtemoc district), the INFONAVIT building (housing institute), Auditorio Nacional (concert hall), the Embassy of Mexico in Brasilia, and many more.

\section{Recapitulation}

Abraham Zabludovsky's work has changed over the years as his professional experience grew. While his early projects, particularly during the academic period and a few following years, were dominated by Le Corbusier's early work, he began to change his view of some issues over time. Interestingly, his change of approach to designing buildings was also consistent with the changes in approach to architecture that his French master underwent. An additional factor binding him with Le Corbusier was a close and long-term cooperation with his pupil, Teodoro Gonzalez de Leon,.

Even Zabludovsky's early approach to design bore many features typical of Brutalist architecture, but over the years they were perfected by him and manifested in subsequent, ever more impressive buildings. First of all, concrete was his material of choice. It has been used both in his own home, and in many multi-family buildings not described above, as well as in the Tamayo Museum and the Colegio de Mexico constructions. His attention towards contextualizing the projects with the places they were to be erected is also worth underlining. Aggregates which he added to the concrete to obtain colors allowing building to fit the surroundings came from places where the structures were built. In the case of the La Patera community, he turned to rough, unmasked material, that is, bricks.

Approach to expressive, strong and varied shape is very freely implemented by Zabludovsky. His buildings are usually quite "heavy" in their appearance, but they are also closely related to the landform on which they are created, adapting to its shape and undulation. Organic lines often appear in them, and the interiors remain either directly connected with the outside, as in the case of vegetation "entering" Colegio de Mexico, or indirectly, like the Tamayo exhibition halls gazing upon the Chapultepec forest through glass panels. The shapes are often heavily fragmented and reveal the nature of activities performed within. 
In terms of architectural detail, Zabludovsky's buildings also remain in line with the philosophy of Brutalism. The materials he used (mainly concrete), are left without finish, but he also utilized the brise soleil, which additionally allowed him not only to include "fashionable" details, but also to rationalize distribution of sunlight, which in Mexican climate may be very aggressive and challenging to architects. This "struggle" with the sun resulted in achieving strong, contrasting shadowand-light effects both on the façades and in the interiors of his projects.

All the features mentioned above clearly indicate that the buildings designed by Zabludovsky are entrenched in the current of Brutalist architecture. Naturally, these are not qualities that he adopted by blindly following his masters. They illustrate his individual approach to design issues, and constitute his own range of design solutions, strongly anchored in his professional experience and personal beliefs about architecture. Zabludovsky's work is all the more valuable for Mexican architecture because it is not a direct transfer of stylistic trends from Europe, but a creative reference to modern currents, and their implementation in the reality of Mexico.

\section{Notas:}

1 In this case, the word "honest" means not covered, not masked with other finishing material, or by changing the form of construction material by finishing the building.

2 The idea of sincerity aimed to clearly show what materials were used to build a structure. It also allowed easy distinction between structural and filling elements. The As Found concept primarily called for building from local materials, and in the surrounding context. A building was supposed to enter into interaction with the surroundings, although this relation did not necessarily have to manifest itself through "fitting”, as it could as well be shown by means of contrast. The Image idea was supposed to evoke strong emotions influencing one's individual reception of the object, as well as the imaginative perception of it. The idea of linking life and architecture compelled to establish the closest possible connection of architectural solutions with the needs of their users.

3 Modulor is a measurement system created by Le Corbusier on the basis of an average human height $-183 \mathrm{~cm}$, or $226 \mathrm{~cm}$ with one hand raised. On the basis of this „typical” man, Le Corbusier created correlations between the dimensions of a building. This system was used, among others, during the design of the Marseilles Unité d'Habitation (1947-52) (Biegański, 1972). After graduation, Gonzalez de Leon took the opportunity to work in the studio of Le Corbusier, and so he succumbed to the influence, and the methods of work of his supervisor.

4 Le Corbusier's five principles: „free plan” is the space freed from restrictions such as walls that cannot be demolished, among others. The application of such a rule would allow users to freely change the interior design, including the room sizes. The other four principles are: free elevation, free ground floor, roof garden, and picture windows. 


\section{References}

Adria, Miguel

2000 Abraham Zabludovsky y la vivienda, Arquine S.A., Ciudad de México Banham, Reyner

1966 The New Brutalism: Ethic or Aesthetic?, Reinhold Publishing Corporation, New York

Bergdoll, Barry, Comes Carlos, Liernur Jorge Francisco and del Real Patricio

2015 Latin America in Construction Architecture 1955-1980, MoMA, New York

Biegański Piotr

$1972 \quad U$ źródeł architektury współczesnej, PWN, Warszawa

Canales Fernanda

2017 Vivienda collectiva en Mexico. El derecho a la arquitectura, Editorial Gustavo Gili, Barcelona

Gonzalez de Leon, Teodoro and Zabludovsky Abraham

1976 Ocho conjuntos de habitacion, arcitectura contemporanea de Mexico, Arcitectura y Sociedad, Mexico

Heyer, Paul

1978 Mexican architecture, the work of Abraham Zabludovsky and Teodoro Gonzalez de Leon, Walker and Company ,New York

Maluga, Leszek

$2015 \quad$ O wędrówce idei, wzorców i motywów w twórczości architektonicznej - przykład Meksyku w: Przyroda, ewolucja, kultura, Oficyna WydawniMaluga, Leszek

cza ATUT - Wrocławskie Wydawnictwo Oświatowe, Wrocław

2017 Mexicans poets of concreto in Defining the architectural space : transmutations of concrete: monograph. Vol. 2, Kraków

Niebrzydowski, Wojciech

2009 Brutalizm w Architekturze - Geneza Kierunku in Architecturae et Artibus - $1 / 2009$

Niebrzydowski, Wojciech

2018 Architektura brutalistyczna a idee Nowego Brutalizmu, Oficyna Wydawnicza Politechniki Białostockiej, Białystok

Website

$$
\begin{aligned}
& \text { http://museotamayo.org } \\
& \text { http://www.bryla.pl } \\
& \text { https://www.archdaily.mx }
\end{aligned}
$$

